\title{
ANALISIS HUBUNGAN KECERDASAN EMOSIONAL DAN LOVE OF MONEY TERHADAP PERILAKU ETIS MAHASISWA (STUDI EMPIRIS PADA MAHASISWA S1 AKUNTANSI UNIVERSITAS PENDIDIKAN GANESHA)
}

\author{
Putu Eka Dianita Marvilianti Dewia,*, I Putu Hendra \\ Martadinata $^{\mathrm{b}}$, Ida Bagus Raminra Padma Diputra \\ $a, b, c$ Universitas Pendidikan Ganesha, Jalan Udayana Nomor 11 Singaraja, \\ Bali, Indonesia \\ *(ekadyanita@gmail.com)
}

\begin{abstract}
ABSTRAK
Penelitian ini menganalisis hubungan antara kecerdasan emosional dan love of money terhadap perilaku etis mahasiswa. Universitas Pendidikan Ganesha menjadi lokasi dalam penelitian ini, tepatnya di program studi S1 Akuntansi. Subjek penelitian yang dijadikan sampel yaitu mahasiswa S1 akuntansi angkatan tahun 2016 dan 2017 dikarenakan mereka telah menempuh mata kuliah akuntasi keperilakuan. Sampel dipilih dengan menggunakan teknik random sampling (sampel acak). Metode pengumpulan data menggunakan kuesioner berupa daftar pertanyaan yang akan diberikan kepada responden. Kuesioner dibagikan saat mahasiswa melakukan bimbingan dalam penyusunan KRS (kartu rencana studi), penulis memberikan ke setiap mahasiswa yang datang untuk bimbingan. Kuesioner yang dibagikan dengan yang kembali berjumlah 76 data. Hipotesis diuji dengan menggunakan teknik analisis regresi linear berganda dengan bantuan program SPSS. Variabel independen terdiri dari kecerdasan emosional dan love of money, sedangkan perilaku etis mahasiswa merupakan variabel dependen. Jenis data yang digunakan yaitu kuantitatif dengan sumber data primer.Berdasarkan hasil analisis dan pembahasan yang telah dilakukan maka perilaku tidak etis mahasiswa dipengaruhi secara positif oleh love of money sedangkan dipengaruhi secara negatif oleh kecerdasan emosional.
\end{abstract}

Kata Kunci: kecerdasan emosional, love of money, perilaku etis.

\begin{abstract}
This study analyzes the relationship between emotional intelligence and love of money on students' ethical behavior. Universitas Pendidikan Ganesha is the location in this study, precisely in the S1 Accounting study program. The research subjects who were sampled were S1 accounting students of the year 2016 and 2017. Samples were selected using random sampling techniques (random samples). Data collection method uses a questionnaire in the form of a list of questions that will be given to respondents. Questionnaires were distributed when students conducted guidance in the preparation of the KRS (study plan card), the author gave to each student who came for guidance. Questionnaires distributed with the return amounted to 76 data. The hypothesis was tested using multiple linear regression analysis techniques
\end{abstract}


with the help of SPSS program. Independent variables consist of emotional intelligence and love of money, while students' ethical behavior is the dependent variable. The type of data used is quantitative with primary data sources. Based on the results of the analysis and discussion that has been done then the unethical behavior of students is positively influenced by love of money while negatively influenced by emotional intelligence.

Keywords: emotional intelligence, love of money, ethical behavior.

\section{PENDAHULUAN}

Manusia pada dasarnya dilahirkan seorang diri, namun di dalam proses kehidupan selanjutnya, manusia membutuhkan manusia lain di sekelilingnya. Ini merupakan salah satu pertanda bahwa manusia itu adalah makhluk sosial yaitu makhluk yang hidup bersama.Dalam rangka mencapai kebutuhan hidup, manusia berinteraksi dengan lingkungan sosial. Mereka melakukan kerjasama dengan orang lain, berteman, bersahabat, bermurah hati, simpati, atau sebaliknya mereka justru melakukan persaingan yang ketat, mementingkan diri sendiri dan lain-lain. Masyarakat merupakan suatu sistem sosial, yang unsur-unsurnya saling mempengaruhi satu dengan yang lainnya. Perubahan salah satu bagian akan mempengaruhi bagian lain, yang akhirnya mempunyai dampak terhadap kondisi sistem secara keseluruhan.

Secara umum kita bisa lihat hal ini pada diri mahasiswa.Mahasiswa jaman sekarang berbeda dengan mahasiswa jaman dahulu yang bisa dilihat dari etika/perilaku mereka baik dalam berkomunikasi secara lisan maupun secara tertulis melalui via sms atau whatsapp dengan dosen yang
bersangkutan.Belakangan ini saya dan juga teman-teman seperguruan saya yang berkarier sebagai dosen juga mulai risih dan mengernyitkan dahi ketika mendapat pesan dari mahasiswa yang tidak etis, seperti contoh: "ibu, hari ini jam berapa ada dikampus? Kira-kira ibu lama ya dikampus?". Hal ini berbeda pada zaman saya mahasiswa, untuk mengirim pesan ke dosen atau berkomunikasi secara lisan saya harus berpikir dalam menggunakan bahasa yang tepat untuk disampaikan agar tidak menyinggung perasaan dosen tersebut.Teman-teman saya sampai harus berkonsultasi ke teman sejawat atau bahkan, mencari waktu yang tepat untuk berkirim pesan.

Perilaku mahasiswa perlu diteliti untuk mengetahui sejauh mana mereka bisa berperilaku etis dan tidak di masa yang akan datang. Perilaku dalam beretika, dapat dibedakan menjadi 2 bagian yaitu perilaku etis yaitu perilaku yang diharapkan oleh masyarakat dan perilaku yang tidak etis yaitu perilaku yang tidak disukai oleh orang lain. Perilaku etis melibatkan pemilihan tindakan-tindakan yang benar atau salah, sesuai dan adil (Hansen \& Mowen, 2007).Masing-masing mahasiswa memiliki etika yang berbeda yang 
ditunjukkan dalam perilaku mereka.Perguruan tinggi dalam hal ini, memiliki andil yang sangat besar dalam membentuk perilaku mahasiswa menjadi seseorang yang profesional sehingga diharapkan dapat memenuhi kebutuhan pasar yang ada dan lulusannya dituntut memiliki kualifikasi keahlian sesuai bidang ilmunya, dan juga memiliki perilaku etis yang tinggi (Hastuti, 2007). Sikap dan perilaku etis akan terbentuk melalui proses pendidikan baik yang berasal dari lingkungan keluarga, masyarakat maupun jenjang pendidikan. Hasil penelitian Malone (2006), menunjukkan jika situasi membahayakan datang pada mahasiswa maka mahasiswa tersebut kemungkinan besar akan berperilaku tidak etis demi keuntungan pribadi mereka.

Salah satu faktor yang mempengaruhi perilaku etis seseorang yaitu kecerdasan emosional. Kecerdasan emosional pertama kali muncul pada 1964 dalam sebuah karya tulis Michael Beldoch, dan pada 1966 dalam karya tulis B Leuner. Emotional intelligence (EI) atau emotional quotient (EQ) didefinisikan sebagai kemampuan seseorang mengendalikan emosi pada diri sendiri dan orang lain. Kecerdasan emosional dapat menuntun seseorang untuk memisahkan berbagai emosi yang dapat digunakan sebagai bahan pemikiran dan perilaku diri sendiri.EQ dinilai dapat memberikan keuntungan dalam bersikap, bahkan dalam berkarier.Kecerdasan emosional mencakup kemampuankemampuan yang berbeda, tetapi saling melengkapi, dengan kecerdasan akademik, yaitu kemampuankemampuan kognitif murni yang diukur dengan Inteligence Quotion (IQ).Banyak orang yang cerdas, dalam arti terpelajar, tetapi tidak mempunyai kecerdasan emosi.Keterampilan EQ bukanlah lawan keterampilan IQ atau keterampilan kognitif, namun keduanya berinteraksi secara dinamis, baik pada tingkatan konseptual maupun di dunia nyata.EQ tidak begitu dipengaruhi oleh faktor keturunan (Shapiro, 1998).Kecerdasan emosional sangat dipengaruhi oleh lingkungan, tidak bersifat menetap, dapat berubah-ubah setiap saat.Gardner dalam bukunya yang berjudul Frame of Mind(Goleman, 2000) mengatakan bahwa bukan hanya satu jenis kecerdasan yang penting untuk meraih sukses dalam kehidupan, melainkan ada spektrum kecerdasan yang lebar dengan tujuh varietas utama yaitu linguistik, matematika/logika, spasial, kinestetik, musik, interpersonal dan intrapersonal.Kecerdasan ini dinamakan oleh Gardner sebagai kecerdasan pribadi yang oleh Daniel Goleman disebut sebagai kecerdasan emosional.

Faktor lain yang mempengaruhi perilaku etis seseorang adalah kecintaan terhadap uang (love of money). Uang merupakan aspek yang sangat penting dalam kehidupan sehari-hari, di Amerika, kesuksesan seseorang diukur dengan banyaknya uang dan pendapatan yang dihasilkan (Ellias, 2010).Beberapa penelitian menunjukkan bahwa konsep the love of money berhubungan dengan 
Dewi, Martadinata, Diputra - Analisis Hubungan Kecerdasan Emosional dan...

beberapa perilaku organisasional yang baik maupun yang tidak diinginkan.Penelitian Tang dan Chiu (2003) menunjukkan bahwa karyawan Hongkong dengan love of money lebih tinggi memiliki kepuasan kerja yang lebih kecil daripada teman kerjanya, sehingga terdapat kemungkinan melakukan tindakan-tindakan yang tidak etis.Studi tersebut juga menunjukkan hubungan yang signifikan antara love of money dan perilaku tidak etis dan memberi label Love of Money merupakan akar dari kejahatan. Penilitian Luna-Arocas dan Tang (2004) memberikan hasil yang berbeda. Mereka berpendapat bahwa love of money dapat membantu memprediksi dan mengendalikan perilaku tidak etis. Hal tersebut didasari karena dengan love of money seseorang dapat memprediksi kepuasan kerja dan kemungkinan perilaku tidak etis. Penelitian mengenai love of money masih terbatas di kalangan mahasiswa, sehingga dibutuhkan investigasi lebih lanjut mengenai potensi love of money dan perilaku etis mahasiswa akuntansi. Penekanan ini dibutuhkan agar mahasiswa lulusan akuntansi lebih mengerti etika dalam profesi. Begitu pula dengan pengajar agar lebih mengerti apakah pendidikan etika selama ini sudah cukup dan baik serta agar pengajar dapat menanamkan pentingnya konseplove of money pada diri mahasiswa, khususnya mahasiswa akuntansi yang nantinya akan berhadapan dengan situasi yang berkaitan dengan uang, terutama dalam dunia kerja. Hal tersebut menunjukkan bahwa studi lebih lanjut mengenai love of money dan persepsi mengenai etika masih sangat dibutuhkan.

Selain beberapa hasil penelitian yang dipaparkan sebelumnya, penulis juga mengacu pada beberapa penelitian utama diantaranya: Martadinata (2017) tentang pengaruh idealisme dan love of money terhadap intensi untuk melakukan manajamen laba dalam pemeberian bonus. Hasil penelitiannya menyatakan" love of money meningkatkan intensi individu untuk berperilaku tidak etis". Penelitian Yuniani (2010) tentang pengaruh kecerdasan emosional terhadap tingkat pemahaman akuntansi.Hasil penelitiannya menyatakan kecerdasan emosional mempengaruhi perilaku mahasiswa dalam memahami akuntansi. Perbedaan penelitian saya dengan penelitian Martadinata (2017) menambahkan satu variabel yaitu kecerdasan emosional sedangkan dengan penelitian Yuniani (2010) variabel terikat yang diteliti yaitu perilaku etis mahasiswa, sehingga disini peneliti menggabungkan dua penelitian tersebut.

Alasan penulis hanya memilih dua variabel bebas disini yaitu kecerdasan emosional adalah kecerdasan yang muncul dari karakter seseorang bukan berdasarkan dari kecerdasan turunan.Kecerdasan emosional (EQ) muncul terlebih dahulu dibandingkan kecerdasan intelektual (IQ).Kecerdasan emosional merupakan kecerdasan dasar seseorang dalam bersikap dan berperilaku dan sangat dipengaruhi oleh lingkungan, tidak bersifat menetap, dapat 
berubah-ubah setiap saat. Sehingga peneliti ingin mengetahui apakah seseorang yang memiliki kecerdasan emosional akan berdampak terhadap perilaku etis mereka. Sedangkan untuklove money berdasarkan penelitianpenelitian terdahulu terdapat perbedaan hasil, beberapa mengatakan bahwa love of money dapat membantu memprediksi dan mengendalikan perilaku tidak etis dan beberapa mengatakan bahwalove of money meningkatkan intensi individu untuk berperilaku tidak etis. Sehingga ada ketertarikan dari peneliti untuk menguji kembali hal tersebut dan ingin mengetahui apakah love of money berpengaruh terhadap perilaku etis mahasiswa. Peneliti mengambil obyek penelitian yaitu mahasiswa S1 Jurusan Akuntansi di Universitas Pendidikan Ganesha, dikarenakan di Universitas ini khususnya di Jurusan S1 Akuntansi menerapkan kebijakan untuk bersikap dan berperilaku yang disiplin seperti, penampilan mahasiswa, cara bertutur kata secara langsung maupun melalui media online, dan sikap disiplin dikelas.

Tujuan dari penelitian ini yaitu, untuk mengetahui pengaruh kecerdasan emosional dan mengetahui pengaruh love of money terhadap perilaku etis mahasiswa.Objek penelitian pada mahasiswa s1 akuntansi Universitas Pendidikan Ganesha.

\section{TELAAH LITERATUR DAN PERUMUSAN HIPOTESIS \\ Virtue Theory (Teori Kebajikan)}

Beberapa teori berusaha untuk menjelaskan perilaku manusia dilihat dari perspektif etika. Salah satu dari teori tersebut adalah virtue theory atau teori kebajikan.Teori ini berangkat dari pemikiran Plato dan Aristoteles yang berbeda dengan beberapa pandangan etika lainnya (Hursthouse, 1999).Berbeda dengan teori deontologi yang berfokus pada kewajiban manusia dan pandangan konsekuensialisme yang berfokus pada konsekuensi dari suatu perbuatan, teori virtue lebih menekankan pada karakter moral individu dalam menjelaskan perilaku etis (Hursthouse, 1999). Agoes dan Ardana (2009) menjelaskan bahwa watak/karakter yang melekat dalam diri individu akan mempengaruhi sikap dan perilaku individu, terutama apabila ditinjau dalam perspektif etika.

Apabila merujuk pada teori virtue, maka dapat disimpulkan bahwa selain dipengaruhi oleh faktor-faktor eksternal, seperti lingkungan, kelompok, tekanan dan sebagainya, perilaku etis sangat dipengaruhi oleh watak/karakter individu. Penelitian ini menduga bahwa karakter individu yang dibentuk oleh kecerdasan emosional akan mempengaruhi perilaku etis individu. Selain itu, di dalam situasi dilema etika tertentu, khususnya pada situasi yang melibatkan uang, penelitian ini menduga bahwa persepsi individu terhadap uang yang diukur melalui skala love of moneyakan mempengaruhi perilaku etis 
endividu. Secara keseluruhan, penelitian ini menduga bahwa watak/karakter yang dilhat dari kecerdasan emosional dan love of moneyakan membentuk sikap dan perilaku individu dalam menghadapi situasi dilema etika.

\section{Kecerdasan Emosional}

Kecerdasan emosi merupakan konsep yang menerima banyak perhatian dalam literatur ilmu sosial beberapa tahun belakangan ini.Seperti pendapat dari (Matthews, 2002) yang mengatakan bahwa tentang pentingnya kepuasan hidup, pencapaian pribadi dan khususnya menjadi sukses dalam dunia bisnis.Pada umumnya, pendapat tersebut berkaitan baik hasil pribadi atau professional dan setiap bidang penting dipertimbangkan bagi seorang pendidik.Salah satu bidang yang jelas diminati untuk para pendidik adalah pengaruh dari kecerdasan emosi dalam prestasi kerja.AICPA dan Institut Akuntansi Manajemen menyadari bahwa keterampilan kecerdasan emosional sangat penting untuk keberhasilan berprofesi sebagai akuntan (Darlene Bay, 2006).

Pentingnya kecerdasan emosional tidak terbatas pada prestasi kerja saja.Bebarapa penelitian telah menyadari interaksi antara kecerdasan emosional dengan kemampuan kepemimpinan.Higgins (2005) telah menyadari pentingnya budaya kecerdasan emosional di dalam perkembangan keberhasilan kepemimpinan global. Kecerdasan emosi merupakan faktor penentu perusahaan dalam karier dan organisasi, termasuk dalam pembuatan keputusan, kepemimpinan, melakukan terobosan teknis dan strategis, komunikasi yang terbuka dan jujur, kerja sama dan hubungan saling mempercayai, serta mengembangkan kreativitas dan daya inovasi (A Cooper, 1998).

Intelegensi emosional atau kecerdasan emosi mengacu pada berbagai keterampilan non-kognitif, kemampuan, serta kompetensi yang memengaruhi kemampuan seseorang untuk berhasil dalam tuntutan lingkungan dan tekanan. Kecerdasan emosional adalah kemampuan untuk mengenali perasaan sendiri maupun orang lain, untuk memotivasi diri sendiri, dan untuk mengendalikan emosi dengan baik, baik dalam diri sendiri, maupun dengan orang lain (Goleman, 1996). Kecerdasan emosi dapat diukur dari beberapa aspek-aspek yang ada. Lubis (2010)mengemukakan lima kecakapan dasar atau dimensi dalam kecerdasan emosi, yaitu:

1. Self Awareness (Kesadaran Diri)

Merupakan kemampuan seseorang untuk mengetahui perasaan dalam dirinya dan efeknya serta menggunakannya untuk membuat keputusan bagi diri sendiri, memiliki tolak ukur yang realistis, atau kemampuan dan mempunyai kepercayaan diri yang kuat lalu mengkaitkannya dengan sumber penyebabnya.

2. Self Management (Kendali Diri) 
Merupakan

kemampuan

menangani emosinya sendiri, mengekspresikan

serta

mengendalikan emosi, memiliki kepekaan terhadap kata hati, untuk digunakan dalam hubungan dan tindakan seharihari.

3. Motivation (Motivasi)

Merupakan

kemampuan

menggunakan hasrat untuk setiap saat membangkitkan semangat dan tenaga untuk mencapai keadaan yang lebih baik serta mampu mengambil inisiatif dan bertindak secara efektif, mampu bertahan menghadapi kegagalan dan frustasi.

4. Social Awareness (Empati)

Merupakan

kemampuan merasakan apa yang dirasakan oleh orang lain, mampu memahami perspektif orang lain, dan menimbulkan hubungan saling percaya serta mampu menyelaraskan diri dengan berbagai tipe individu.

5. Relationship

Management

(Keterampilan Sosial)

Merupakan

kemampuan

menangani emosi dengan baik ketika berhubungan dengan orang lain dan menciptakan serta mempertahankan

hubungan dengan orang lain, bisa mempengaruhi, memimpin, bermusywarah, menyelesaikan perselisihan dan bekerja sama dalam tim.

\section{Love Of Money}

Uang merupakan salah satu dasar yang sering digunakan oleh seseorang untuk mengambil suatu keputusan. Bahkan bagi beberapa individu, uang merupakan tujuan utama yang harus dicapai untuk memenuhi kebahagiannya. Tak jarang uang dapat menjerumuskan beberapa individu untuk melakukan tindakan yang tidak etis. Maka dari itu, uang merupakan salah satu faktor yang dapat mempengaruhi perilaku etis seseorang.

Beberapa penelitian mencoba untuk menjelaskan perilaku etis individu secara empiris dengan melihat aspek kecintaan individu terhadap uang. Salah satu ukuran yang sering digunakan untuk mengukur sikap dan pandangan individu terhadap uang adalah skala love of money (LOM) yang dikembangkan oleh Tang (1992) dalam Tang dan Chen (2008). Love of money merupakan ukuran yang menggambarkan tingkat keinginan, penilaian, ekspektasi, maupun aspirasi individu terhadap uang (Tang dan Chen, 2008). Individu yang memiliki kecintaan terhadap uang yang tinggi memandang bahwa uang merupakan motivator utama dan merupakan ukuran kesuksesan dan kebahagiaannya (Tang dan Chiu, 2003; Tang dan Liu, 2012), sehingga tak jarang uang dapat menjerumuskan beberapa individu ke dalam perilaku yang melanggar etika dan hukum. Hal tersebut didukung oleh pernyataan Tang dan Chiu (2003) bahwa perilaku tidak etis berakar 
dari love of money yang terdapat dalam diri individu.

Beberapa penelitian telah menguji pengaruh love of money terhadap perilaku etis individu. Singhapakdi dkk. (2013) dan Wang dan Yang (2016) menemukan bahwa kecenderungan individu untuk tidak peduli terhadap permasalahan etika dan berperilaku tidak etis ditunjukkan oleh individu dengan love of money yang tinggi. Selain itu, sejalan dengan Singhapakdi dkk. (2013) dan Wang dan Yang (2016), Chen, Tang, dan Tang(2014) yang meneliti tentang kecurangan menemukan bahwa love of money menyebabkan individu untuk berperilaku curang dalam mengerjakan tugas. Dari beberapa penelitian tersebut, dapat disimpulkan bahwa love of money dapat mendorong individu untuk berperilaku tidak etis, terutama dalam situasi yang melibatkan uang. Ketika dihadapkan dalam situasi yang melibatkan uang, individu dengan love of money yang tinggi cenderung mengabaikan aspek etika dalam pengambilan keputusannya. Hal tersebut disebabkan oleh pandangan individu bahwa uang adalah sumber kebahagiaan dan kesuksesan, sehingga rela untuk bertindak apapun demi mendapatkan uang tanpa memandang aspek etika dalam tindakannya.

\section{Kecerdasan Emosional dan Perilaku Etis}

Kecerdasan emosional dapat menuntun seseorang untuk memisahkan berbagai emosi yang dapat digunakan sebagai bahan pemikiran dan perilaku diri sendiri. Jordan (2006) mengemukakan pula bahwa kecerdasan emosional memegang peranan penting untuk memprediksi kinerja suatu tim. EQ dinilai dapat memberikan keuntungan dalam bersikap, bahkan dalam berkarier. Kecerdasan emosi merupakan faktor penentu perusahaan dalam karier dan organisasi, termasuk dalam pembuatan keputusan, kepemimpinan, melakukan terobosan teknis dan strategis, komunikasi yang terbuka dan jujur, kerja sama dan hubungan saling mempercayai, serta mengembangkan kreativitas dan daya inovasi (A Cooper, 1998).Penelitian Yuniani (2010) tentang pengaruh kecerdasan emosional terhadap tingkat pemahaman akuntansi.Hasil penelitiannya menyatakan kecerdasan emosional mempengaruhi perilaku mahasiswa dalam memahami akuntansi.Di samping itu, Fu (2014) serta Hopkins dan Deepa (2018) menemukan bahwa kecerdasan emosional berpengaruh positif terhadap perilaku etis individu, serta dapat membentuk ethical ideology pada individu. Maka dari itu, hipotesis yang diajukan adalah:

$$
\begin{array}{rlr}
H_{1}: & \text { Kecerdasan } & \text { Emosional } \\
& \text { berpengaruh negatif terhadap } \\
& \text { perilaku tidak etis mahasiswa }
\end{array}
$$

\section{Love Of Money dan Perilaku Etis}

Beberapa penelitian menunjukkan bahwa konsep the love of money berhubungan dengan beberapa perilaku organisasional yang baik maupun yang tidak diinginkan. Individu yang memiliki kecintaan terhadap uang yang tinggi 
memandang bahwa uang merupakan motivator utama dan merupakan ukuran kesuksesan dan kebahagiaannya (Tang dan Chiu, 2003; Tang dan Liu, 2012), sehingga tak jarang uang dapat menjerumuskan beberapa individu ke dalam perilaku yang melanggar etika dan hukum. Hal tersebut didukung oleh pernyataan Tang dan Chiu (2003) bahwa perilaku tidak etis berakar dari love of money yang terdapat dalam diri individu. Penelitian Martadinata menyatakan" love of money meningkatkan intensi individu untuk berperilaku tidak etis". Singhapakdi dkk. (2013) dan Wang dan Yang (2016) menemukan bahwa kecenderungan individu untuk tidak peduli terhadap permasalahan etika dan berperilaku tidak etis ditunjukkan oleh individu dengan love of money yang tinggi. Dari beberapa penelitian tersebut, dapat disimpulkan bahwa love of money dapat mendorong individu untuk berperilaku tidak etis, terutama dalam situasi yang melibatkan uang.Maka dari itu, hipotesis yang diajukan adalah:

$\mathrm{H}_{2}$ : Love of money berpengaruh positif terhadap perilaku tidak etis mahasiswa

\section{METODE PENELITIAN}

Universitas Pendidikan Ganesha menjadi lokasi dalam penelitian ini, tepatnya di program studi S1 Akuntansi.Objek penelitian yang dijadikan sampel yaitu mahasiswa S1 akuntansi angkatan tahun 2016 dan 2017. Sampel dipilih dengan menggunakan teknik random sampling (sampel acak) yaitu sesuatu cara pengambilan sample yang memberikan kesempatan atau peluang yang sama untuk diambil kepada setiap elemen populasi. Maka seluruh mahasiswa S1 Akuntansi berkesempatan menjadi sampel. Metode pengumpulan data menggunakan kuesioner berupa daftar pertanyaan yang akan diberikan kepada responden. Kuesioner dibagikan saat mahasiswa melakukan bimbingan dalam penyusunan KRS (kartu rencana studi), penulis memberikan ke setiap mahasiswa yang datang untuk bimbingan.Kuesioner yang dibagikan dengan yang kembali berjumlah 76 data.Kuesioner kecerdasan emosional memuat tentang kemampuan pengenalan diri, pengendalian diri, motivasi, mempunyai rasa empati, dan ketrampilan sosial yang merupakan modifikasi dari kuesioner Ani Sapariyah dkk. (2016). Sedangkan kuesioner love of money memuat tentangpekerjaan, sistem reward, motivasi dari dalam diri pada pekerjaan yang pada perputarannya dapat mempengaruhi perilaku dalam pekerjaan, task performance, kepuasan kerja dan moral, serta efektivitas organisasi dan modifikasi dari kuesioner Elias (2010). Perilaku etis dalam penelitian ini menggunakan instrumen yang diadopsi dari penelitian Martadinata (2017).Dalam instrumen tersebut, perilaku etis diukur berdasarkan tingkat persetujuan responden untuk melakukan manajemen laba demi memperoleh bonus untuk dirinya sendiri.Kasus manajemen laba 
Dewi, Martadinata, Diputra - Analisis Hubungan Kecerdasan Emosional dan...

merupakan kasus etika yang paling penting dalam dunia akuntansi (Merchant dan Rockness, 1994), sehingga hal tersebut melatarbelakangi peneliti untuk menggunakan kasus manajemen laba.

Hipotesis diuji dengan menggunakan teknik analisis regresi linear berganda dengan bantuan program SPSS. Variabel independen terdiri dari kecerdasan emosional dan love of money, sedangkan perilaku etis mahasiswa merupakan variabel dependen.Jenis data yang digunakan yaitu kuantitatif dengan sumber data primer.

\section{HASIL DAN PEMBAHASAN}

Responden penelitian ini adalah mahasiswa sarjana jurusan Akuntansi Program S1 Undiksha tahun angkatan 2016 dan 2017.Populasi dalam penelitian ini berjumlah 76 orang dan menggunakan sampel jenuh.Menurut Arikunto (2012:104) jika populasinya kurang dari 100 orang, maka jumlah sampelnya diambil secara keseluruhan. Sehingga total sampel yang digunakan sebanyak 76 orang. Total data responden yang berhasil dikumpulkan untuk dilakukan analisis adalah sebanyak 76 data. Dari 76 responden, 37 orang $(48.7 \%)$ di antaranya merupakan mahasiswa tahun angkatan 2016, sedangkan 39 orang $(51,3 \%)$ merupakan mahasiswa tahun angkatan 2017. Dilihat berdasarkan jenis kelamin, sebanyak 27 orang responden $(35,5 \%)$ berjenis kelamin laki-laki, sedangkan 49 responden (64,5\%) berjenis kelamin perempuan. Rata-rata umur responden adalah 20 tahun, dengan sebagian besar responden berumur 19 tahun $(43,4 \%)$. Berikut merupakan tabel statistik deskriptif penelitian ini:

Tabel 1. Statistik Deskriptif

\begin{tabular}{|c|c|c|c|}
\hline & Keterangan & Jumlah & $\begin{array}{c}\text { Persentase } \\
(\%)\end{array}$ \\
\hline Tahun & Angkatan 2016 & 37 & 48,7 \\
\hline \multirow[t]{2}{*}{ Angkatan } & Angkatan 2017 & 39 & 51,3 \\
\hline & Total & 76 & 100 \\
\hline \multirow[t]{3}{*}{ Jenis Kelamin } & Laki-laki & 27 & 35,5 \\
\hline & Perempuan & 49 & 64,5 \\
\hline & Total & 76 & 100 \\
\hline \multirow[t]{6}{*}{ Umur } & 18 tahun & 3 & 3,9 \\
\hline & 19 tahun & 33 & 43,4 \\
\hline & 20 tahun & 21 & 27,6 \\
\hline & 21 tahun & 16 & 21,1 \\
\hline & 22 tahun & 3 & 3,9 \\
\hline & Total & 76 & 100 \\
\hline
\end{tabular}

Sumber: Data diolah (2018) 


\section{Uji Asumsi Klasik}

Uji asumsi klasik dilakukan sebelum model penelitian diuji dengan menggunakan metode analisis regresi linier.Uji asumsi klasik yang dilakukan adalah uji normalitas, heteroskedastisitas, dan multikolinieritas.Berdasarkan hasil uji normalitas dengan menggunakan P-P plot, ditemukan bahwa data penelitian ini berdistribusi normal.Untuk uji heteroskedastisitas, penelitian ini menggunakan metode Glejser. Berdasarkan hasil uji heteroskedastisitas dengan menggunakan metode Glejser pada Tabel 1, diperoleh hasil bahwa data penelitian terbebas dari masalah heteroskedastisitas dengan nilai Sig. masing-masing sebesar 0,514 dan 0,436 untuk Emotional Quotients dan Love of Money ( $\mathrm{p}>0,05)$. Sedangkan untuk uji multikolinieritas, seperti yang terlihat pada Tabel 2, diperoleh hasil bahwa data penelitian memenuhi asumsi multikolinieritas dengan nilai VIF masing-masing sebesar 1,046 untuk Emotional Quotients dan Love of Money (VIF < 10). Dari hasil yang telah diperoleh, maka data penelitian ini telah memenuhi asumsi klasik sehingga dapat dilakukan pengujian hipotesis dengan menggunakan uji regresi linear. Beikut merupakan gambaran hasil uji asumsi klasik yang telah dilakukan:



Gambar 1.Normal P-P Plot 
Tabel 1.Hasil Uji Glejser

\begin{tabular}{llll} 
& Model & Sig. \\
& & & \\
\hline $1 \quad$ (Constant) & .883 \\
& Emotional Quotients & .514 \\
& Love of Money & .436 \\
\hline
\end{tabular}

Sumber: Data diolah (2018)

Tabel 2. Hasil Uji Multikolinieritas

\begin{tabular}{llll}
\hline \multirow{2}{*}{ Model } & $\begin{array}{l}\text { Collinearity Statistics } \\
\text { Tolerance }\end{array}$ & VIF \\
\hline 1 & (Constant) & & \\
& Emotional Quotients & .956 & 1.046 \\
& Love of Money & .956 & 1.046 \\
\hline
\end{tabular}

Sumber: Data diolah (2018)

\section{Hasil Uji Hipotesis}

Berdasarkan data Tabel 3 menunjukkan bahwa $26,4 \%$ dari total dapat dilihat nilai $\mathrm{R}$ sebesar 0,514. varians variabel dependen (perilaku Hal tersebut menunjukkan tingkat etis) dapat dijelaskan oleh variabel korelasi variabel yang tergolong tinggi. independen (emotional quotients dan Sedangkan nilai $\mathrm{R}$ Square yang love of money). diperoleh sebesar 0,264. Hal tersebut

Tabel 3.Model Summary Adjusted R

Model R R Square Square $\quad$ Std. Error of the Estimate

$\begin{array}{lllll}1 & .514^{\mathrm{a}} & .264 & .244 & 1.166\end{array}$

a. Predictors: (Constant), Emotional Quotients, Love of Money Sumber: Data diolah (2018)

Tabel 4. Hasil Uji Hipotesis

\begin{tabular}{|c|c|c|c|c|c|c|}
\hline & \multirow{2}{*}{ Model } & \multicolumn{2}{|c|}{$\begin{array}{l}\text { Unstandardized } \\
\text { Coefficients }\end{array}$} & \multirow{2}{*}{$\begin{array}{c}\text { Standardized } \\
\text { Coefficients }\end{array}$} & \multirow[t]{2}{*}{$\mathrm{T}$} & \multirow{2}{*}{ Sig. } \\
\hline & & $\mathrm{B}$ & Std. Error & & & \\
\hline \multirow[t]{3}{*}{1} & (Constant) & 9.188 & 1.997 & & 4.602 & .000 \\
\hline & Emotional Quotients & -.224 & .054 & -.426 & -4.144 & .000 \\
\hline & Love of Money & .026 & .007 & 390 & 3.801 & .000 \\
\hline
\end{tabular}

a. Dependent Variable: Perilaku Etis

Sumber: Data diolah (2018) 
Dari hasil uji hipotesis seperti yang tertera pada tabel di atas dapat dilihat bahwa variabel Emotional Quotients (EQ) memiliki nilai Sig. sebesar 0,000 $(\mathrm{p}<0,01)$ dengan nilai B sebesar -0,224. Nilai tersebut menunjukkan bahwa terdapat hubungan negatif dan signifikan antara EQ dan kecenderungan perilaku tidak etis mahasiswa. Dengan kata lain, kecenderungan mahasiswa untuk berperilaku tidak etis cenderung menurun seiring dengan meningkatnya kecerdasan emosional yang dimiliki oleh mahasiswa. Dengan demikian, hipotesis pertama $\left(H_{1}\right)$ penelitian ini terdukung dan mendukung hasil penelitian Yuniani (2010) yang menyatakan kecerdasan emosional mempengaruhi perilaku mahasiswa dalam memahami akuntansi.

Untuk variabel Love of Money (LoM), berdasarkan hasil tabel diatas menunjukkan bahwa nilai Sig. variabel LoM sebesar 0,000 $(p<0,01)$ dan koefisien B sebesar 0,026. Hal tersebut mengindikasikan bahwa terdapat hubungan positif yang signifikan antara Love of Money terhadap kecenderungan perilaku tidak etis mahasiswa, sehingga hipotesis kedua $\left(H_{2}\right)$ penelitian ini terdukung dan mendukung hasil penelitian Martadinata (2017) dan
Singhapakdi dkk. (2013) dan Wang dan Yang (2016) yang menyatakan bahwa love of money dapat mendorong individu untuk berperilaku tidak etis, terutama dalam situasi yang melibatkan uang. Love of money yang tinggi dalam diri mahasiswa akan meningkatkan kecenderungan perilaku tidak etis mahasiswa pada situasi yang melibatkan uang. Secara keseluruhan, kedua hipotesis yang diajikan dalam penelitian ini terdukung.

\section{Pembahasan}

Seperti yang telah dibahas sebelumnya, Goleman menyatakan bahwa kemampuan individu untuk mengenali perasaan diri sendiri maupun orang lain, memotivasi diri sendiri, dan kemampuan untuk mengendalikan emosi sangat dipengaruhi oleh kecerdasan emosional individu.Apabila dikaitkan dengan aspek etika, kecerdasan emosional dapat mempengaruhi individu dalam membuat keputusan etis. Seseorang dapat berperilaku atau membuat keputusan etis apabila individu tersebut memiliki kecakapan dasar atau dimensi kecerdasan emosional yang diungkapkan oleh Lubis (2010), yaitu kesadaran diri, kendali diri, 
motivasi, empati, dan keterampilan sosial.

Ketika individu memiliki kesadaran diri dan kendali diri, individu dapat menganalisa dampak dari tindakan yang akan dilakukan. Perilaku tidak etis sering kali menghasilkan dampak yang negatif, terutama untuk individu lainnya dan bahkan dapat merugikan dirinya sendiri. Individu yang sadar akan hal tersebut akan sangat berhati-hati untuk mengendalikan perilaku maupun tindakannya agar tidak melanggar prinsip etika, sehingga tidak merugikan dirinya sendiri maupun orang lain. Hal tersebut dapat dikaitkan ke aspek empati, yaitu kepedulian terhadap individu lainnya.

Menyangkut tentang aspek motivasi, Lubis (2010) menyatakan bahwa motivasi dapat membangkitkan semangat untuk mencapai keadaan yang lebih baik serta mampu mengambil inisiatif dan bertindak secara efektif.Apabila dikaitkan dengan aspek etika, individu yang memiliki motivasi yang tinggi memiliki dorongan yang kuat untuk berperilaku sesuai dengan aturan etika. Selain itu, keterampilan sosial akan menguatkan dorongan tersebut, karena pada dasarnya individu yang memiliki keterampilan sosial berusaha untuk menciptakan hubungan yang harmonis antar individu, dalam hal ini adalah hubungan antar individu di lingkungan kampus. Untuk mencapai keharmonisan tersebut, hal yang dapat dilakukan salah satunya adalah dengan bertindak dan berperilaku sesuai dengan etika yang berlaku di lingkungan kampus.Maka dari itu, mahasiswa yang memiliki kecerdasan emosional yang tinggi pada umumnya mampu menunjukkan perilaku etis di lingkungan kampus.

Selain kecerdasan emosional, penelitian ini menemukan bahwa love of money dapat memengaruhi perilaku etis individu.Mahasiswa, khususnya mahasiwa akuntansi, di dalam pelaksanaan kuliahnya sering dipaparkan materi yang berorientasi pada uang.Hal tersebut dapat membentuk pola pikir mahasiswa akuntansi, bahwa aspek penting dalam suatu bisnis adalah laba.Pola pikir tersebut kemungkinan besar dapat terbawa hingga mahasiswa sudah terjun ke dunia kerja.Pola pikir tersebut dapat dikaitkan pada konsep love of money, yang berpandangan bahwa uang merupakan simbol kesuksesan (Tang dan Chiu, 2003; Tang dan Liu, 2012). Maka dari itu, konsisten dengan hasil penelitian ini, individu yang memiliki pandangan bahwa uang merupakan simbol 
kesuksesan cenderung tidak peduli terhadap etika demi mendapatkan uang.

\section{SIMPULAN DAN SARAN}

Berdasarkan hasil analisis dan pembahasan yang telah dilakukan maka perilaku etis mahasiswa dipengaruhi secara positif oleh love of money sedangkan dipengaruhi secara negatif oleh kecerdasan emosional.Love of money yang tinggi dalam diri mahasiswa akan meningkatkan kecenderungan perilaku tidak etis mahasiswa pada situasi yang melibatkan uang. Kecintaan seseorang pada uang membuat orang tersebut melekat pada uang, sehingga tujuan hidupnya hanya sekedar mencari materi atau uang saja, dan akan berusaha untuk memperoleh uang dan membelanjankannya sesuai keinginan, bahkan dalam mencari serta membelanjakan uang/materi harus dengan cara yang tidak benar atau tidak sesuai etika. Sedangkan semakin tinggi kecerdasan emosional seseorang maka semakin rendah perilaku tidak etis seseorang.Hal ini dikarenakan kecerdasan emosional memuat tentang kemampuan pengenalan diri, pengendalian diri, motivasi, mempunyai rasa empati, dan ketrampilan sosial. Sehingga seseorang yang memilki kecerdasan emosional yang tinggi mereka akan enggan melakukan perilaku tidak etis. Saran yang bisa diberikan mengingat data empiris tidak sepenuhnya mendukung model hipotesis dalam penelitian ini, maka untuk penelitian selanjutnya perlu dipertimbangkan: (a) menambah jumlah sampel agar didapat hasil yang lebih akurat, mengembangkan angket yang lebih valid dan handal, dan (c) perlu mengamati variabel-variabel lain di luar EQ (kecerdasan emosional) dan love of money misalnya melakukan observasi yang lebih banyak dengan menambah variabel pendukung sepeti gender, pendidikan, dan lain-lain.

\section{DAFTAR PUSTAKA}

A Cooper, A. S. 1998.Executive EQ: Kecerdasan Emosional dalam Kepemimpinan danOrganisasi.Jakarta: PT Gramedia Pustaka Utama.

Agoes, Sukrisno., dan Ardana, I Cenik. 2009. Etika Bisnis dan Profesi: Tantangan Membangun Manusia Seutuhnya. Jakarta: Salemba.

Chen, Jingqiu, Thomas Li-Ping Tang, dan Ningyu Tang. 2014. Temptation, Monetary Intelligence (Love of Money), and Environmental Context on Unethical Intentions and Cheating. Journal of Business Ethics 123, no. 2: 197-219.

Darlene Bay, K. M. 2006. Emotional Intelligence in Undergraduate 
Accounting

Students:Preliminary

Assessment.Accounting

Education: An International Journal, 439-454.

Elias, R. Z. Dan Farag, M. S. 2010. The Relationship Between Accounting Students' Love of Money and Their Ethical Perception. Managerial Auditing Journal, Vol. 25 Iss: 3, pp.269281.

Fu, W. 2014.The impact of emotional intelligence, organizational commitment, and job satisfaction on ethical behavior of Chinese employees.Journal of Business Ethics, 122(1), 137144.

Goleman, D. 1996. Emotional Intelligence.London:

Blooomsbury.

Goleman, Daniel. 2000.Emotional Intelligence: Mengapa EQ Lebih Penting daripada IQ. Gramedia Pustaka Utama: Jakarta.

Hansen, D.R., dan Mowen, M.M. 2007. Akuntansi Manajerial. Jakarta: Salemba Empat.

Hastuti,Sri.2007.Perilaku Etis Mahasiswa dan Dosen Ditinjau dari Faktor Individual Gender dan Locus of Control.Jurnal Riset Ekonomi dan BisnisVolume 7 Nomor1.

Higgins, I. A. 2005. Global Leadership Success Through Emotional and Cultural Intelligences.501-512

Hopkins, M., \& Deepa, R. 2018.The impact of emotional intelligence on ethical judgment.Journal of Management Development.

Hursthouse, Rosalind. (1999). On Virtue Ethics.OUP Oxford.
Jordan, Peter J. 2006. Emotional Intelligence in Team:Development and Initial Validation of the Short Version of the Workgroup Emotional Intelligence Profile.Journal of Management Organization,pp:452-469, Australian and New Zealand.

Lawrence, E Shapiro.2001. Mengajarkan Emotional Intelligence Pada Anak. Jakarta: Gramedia Pustaka Utama.

Lubis, A. I. 2010. Akuntansi Keperilakuan. Jakarta: Salemba Empat.

Malone,F.L. 2006. The Ethical Attitudes os Accounting Students.Journal of The American Academy of Business, Vol.8, No.1:142-146.

Martadinata, Hendra.2017.Pengaruh Idealisme dan Love of Money Terhadap Intensi untuk Melakukan Manajemen Laba dalam Skema Pemberian Bonus.Tesis: Universitas Gadjah Mada.

Matthews, G. 2002.Emotional Intelligence: Science and Myth. Cambridge, MA: The MIT Press.

Merchant, K. A., dan Rockness, J. 1994. The Ethics of Managing Earnings: An Empirical Investigation. Journal of Accounting and Public Policy, 13(1), 79-94.

Sapariyah, A.R., Yanti, S., dan Arief, B.D. 2016.Pengaruh Muatan Etika dalam Pengajaran Akuntansi Keuangan, Kecerdasan Intelektual, Kecerdasan Emosional, dan Religiusitas terhadap Sikap Etis Mahasiswa Akuntansi (Studi Pada Mahasiswa Akuntansi di 
Surakarta).Jurnal Paradigma, Vol. 13, No. O2, ISSN: 16930827.

Singhapakdi, Anusorn, Scott J. Vitell, Dong-Jin Lee, Amiee Mellon Nisius, dan B. Yu Grace. 2013. The Influence of Love of Money and Religiosity on Ethical Decision-Making in Marketing. Journal of Business Ethics 114, no. 1: 183-191.

Sugiyono. 2012. Metode Penelitian Kualitatif dan R\&D. Bandung: Alfabeta.

Tang,T., dan Chiu, R. 2003.Income, Money Ethics, Pay Satisfaction, Commitment, and Unethical Behavior: Is the Love of Money the Root of Evil for Hongkong Employees? Journal of Business Ethics, Vol. 46, pp.13-30.

Tang,T., Tillery,K.,Lazarevski,B., dan Luna-Arocas, R. 2004. The Love of Money and WorkRelated Attitudes:Money Profiles in Macedonia. Journal of Managerial Psychology.Vol.19, No.5, pp.542-8.

Tang, Thomas Li-Ping, dan Hsi Liu. 2012. Love of Money and Unethical Behavior Intention: Does an Authentic Supervisor's Personal Integrity and Character (ASPIRE) Make a Difference? Journal of Business Ethics 107, no. 3: 295-312.

Tang, Thomas Li-Ping, dan Randy K. Chiu. 2003. Income, Money Ethic, Pay Satisfaction, Commitment, and Unethical Behavior: Is the Love of Money the Root of Evil for Hong Kong Employees? Journal of Business Ethics 46, no. 1: 13-30.

Tang, Thomas Li-Ping, dan Yuh-Jia Chen. 2008. Intelligence vs. Wisdom: The Love of Money, Machiavellianism, and
Unethical Behavior across College Major and Gender. Journal of Business Ethics 82, no. 1: 1-26.

Tang, Thomas Li-Ping. 1992. The Meaning of Money Revisited. Journal of Organizational Behavior 13, no. 2: 197-202.

Wang, Yau-De, dan Conna Yang. 2016. How Appealing are Monetary Rewards in the Workplace? A Study of Ethical Leadership, Love of Money, Happiness, and Turnover Intention. Social Indicators Research 129, no. 3: 12771290.

Yuniani, Anggun. 2010. Pengaruh Kecerdasan Emosional Terhadap Pemahaman Akuntansi (Studi Empiris pada Mahasiswa Akuntansi Universitas Diponegoro Semarang). Fakultas Ekonomi Universitas Diponegoro. 